\title{
First genetic record and the phylogenetic relationship of Osteochilus spilurus (Cyprinidae: Labeoninae ) originating from Bangka and Belitung Islands, Indonesia
}

\author{
ARDIANSYAH KURNIAWAN ${ }^{1,2, \bullet}$, ANIK M. HARIATI ${ }^{3}$, ANDI KURNIAWAN ${ }^{3}$, DEWA G.R. WIADNYA ${ }^{3 \bullet \bullet}$ \\ ${ }^{1}$ Doctoral Program, Faculty of Fisheries and Marine Science, Universitas Brawijaya. Jl. Veteran, Malang 65145, East Java, Indonesia. \\ Tel.: +62-341-553512, Fax.: +62-341-557837, •email: ardian_turen@yahoo.co.id/ardikurniawan@student.ub.ac.id \\ ${ }^{2}$ Department of Aquaculture, Faculty of Fisheries, Agriculture and Biology, Universitas Bangka Belitung. Jl. Kampus Peradaban Balunijuk, Merawang \\ Bangka 33172, Bangka Belitung Islands, Indonesia \\ ${ }^{3}$ Faculty of Fisheries and Marine Science, Universitas Brawijaya. Jl. Veteran, Malang 65145, East Java, Indonesia \\ Tel.: +62-341-553512, Fax.: +62-341-557837, •"email: dgr_wiadnya@ub.ac.id
}

Manuscript received: 30 November 2020. Revision accepted: 16 January 2021.

\begin{abstract}
Kurniawan A, Hariati AM, Kurniawan A, Wiadnya DGR. 2021. First genetic record and the phylogenetic relationship of Osteochilus spilurus (Cyprinidae: Labeoninae) originating from Bangka and Belitung Islands, Indonesia. Biodiversitas 22: $794-802$. Osteochilus spilurus is a freshwater fish from Southeast Asia. Species identification for this fish in Indonesia is still solely limited to morphological characteristics. Therefore it is highly important to validate using short DNA sequences that have been proven to be fast, effective, and accurate. Fish specimens were collected from Lenggang river in Belitung island, and Lebak river in Bangka island, Indonesia. Mitochondrial cytochrome b gene (cyt b, 408 bp) was amplified and sequenced. We collected fish specimens from Lenggang River in Belitung Island and Lebak River in Bangka Island, Indonesia. The results suggested that individuals from both islands are clustered together with a strong bootstrap value $(100 \%)$ in a monophyletic clade. The specimens deposited at NCBI as the first Indonesian genetic records. They have a sister lineage to individuals from Sabah, Malaysia, although supported by a low bootstrap value. While geographical connection during the Pleistocene period allowed wide distribution of the species, differences in the evolutionary processes of historical biogeography and environmental changes are the predicted cause of the low genetic similarity. These findings can be used as a sequence reference and basic information for conservation of this species.
\end{abstract}

Keywords: Cytochrome b, mtDNA, Osteochilus, Sundaland

\section{INTRODUCTION}

Osteochilus spilurus is native freshwater fish in Indonesia, widely distributed in Southeast Asia. Previous studies have shown that geographic distribution of this species is Sundaland, including in Thailand, Malay Peninsula, Borneo, and Sumatra Island (Kottelat et al 1993; Fahmi et al. 2015; Haryono and Wahyudewantoro 2020; Lumbantobing and Huckstorf 2020). They are usually found in acidic water of low-velocity rivers. The fish marked black blotch at the base of the tail and has a length of not more than $10 \mathrm{~cm}$ are benthopelagic (live between the surface and deep water areas). They also like to move in groups with other small fish and are positioned at the bottom of the group. There are no publications that specifically discuss $O$. spilurus apart from Bangka and Belitung Islands. Most of the publications indicate the existence of this species as an ichthyofauna in the freshwater river.

Osteochilus spilurus is not a common fish in Indonesia. They have not got a national tag. For this species, each island has a local name. They are Toros in Malaysia, Seluang Licin in Central Borneo, Seluang Sungai in southern Sumatra, Kepait in Bangka island, and Cempedik in Belitung island (Huckstorf 2012; Muslih et al. 2014;
Fakhrurrozi et al. 2016; Kurniawan et al. 2020a). This fish is known by almost all Belitung people but is only known by anglers on other islands. Belitung community likes to consume this slightly bitter-tasting fish as a protein source (Kurniawan et al. 2016). Even these fish are included in society's culture with the emergence of ethnic songs and Batik with the theme of Cempedik.

The economic value of $O$. spilurus has increased due to demand and habit of Belitung residents to consume it, especially in East Belitung (Kurniawan and Triswiyana 2019). This fish, which was the least concern, now needs serious attention due to the exploitation of nature and its trade. Consumption of fish relying on the natural catch can pressure its natural population. Pragmatically, fish domestication will reduce the burden on the natural ecosystem through fishing while satisfying consumer demand. Kurniawan et al. (2019) have started the first level domesticated as aquaculture commodities, and related aspects of fish domestication are studied in more detail by Radona et al. (2020). At present, O. spilurus is in the first stage of domestication. Fish have been able to live in artificial containers on this level. Treatment of running water is a critical finding in the domestic process (Kurniawan et al. 2019). Stress and fish mortality decreased when the water in the container flowed even 
though in low debit.

However, there is a gap problem that has not been prepared before entering domestication. This species has not been identified molecularly. Nowadays, the identification of $O$. spilurus in Indonesia is still limited to its morphological characters (Kurniawan et al. 2020b; Mustikasari et al. 2018). The morphological approach has a weakness because a phenotype change in fish may cause an uncertain deviation in species validation. Although the meristic character is according to the description of Weber and de Beaufort (1916), O. spilurus from Bangka and Belitung island has a significant difference in eight morphometric characters and the body shape (Kurniawan et al. 2020b; Kurniawan et al. 2020c). The cause of the morphological variation cannot be ascertained when the fish originated from two different islands. However, when genetic variations cause phenotypic variations, it can refute or complement the argument for ecological adaptation. Its molecular information needed in preparation for the breeding stage of domestication. Genetic records are useful for comparing subsequent identifications, considering genetic diversity, and compiling phylogeography across regions. Genetic identification is necessary to certainty and more specific species identification where traditional methods cannot be applied (Ward et al. 2009).

Mitochondrial DNA genes, which are widely used in fish identification, can also molecularly validate $O$. spilurus species. Bangka and Belitung, the two biggest islands in Bangka-Belitung Islands Province and have economic use in one of them, require molecular investigation to confirm their phylogenetic position. However, the lack of genetic studies of this species makes it necessary to adjust the type of gene used in molecular identification. There is only one database source of $O$. spilurus genetic sequences available at the National Center for Biotechnology Information (NCBI 2019). The nucleotides are a specimen of Tawau River, Sabah,
Malaysia, with 408 base pair (bp) cytochrome b (Cyt b) gene primary (Esa et al. 2012). A fragment of the mitochondrial cytochrome b (Cytb) gene is a frequently used marker for reconstructing species-level relationships. Cyt $b$ has been used for species identification and phylogenetic studies (Hsieh et al. 2001). In this study, we used the 408 bp region of the mitochondrial cytochrome $b$ gene to equate the cytochrome $b$ fragments used in the previous record by Esa et al. (2012). This finding will be a valuable benefit for species validation and future identification references. The absence of $O$. spilurus gene records from Indonesia in the GenBank provides an opportunity for this research to produce the first record. Gene bank records are expected to reflect increased attention to $O$. spilurus, which is considered the least concern in other Southeast Asia regions. Still, it is possible at a more dangerous level to the population of Belitung Island, especially East Belitung.

\section{MATERIALS AND METHODS}

\section{Sample source}

Live fish specimens were collected from the catches of local fishermen in Kepulauan Bangka-Belitung Province, Indonesia. The sample location was determined by interview and verified before sampling from any single source. Random samples of each wild Osteochilus spilurus were collected in Lebak River, Payabenua Village, Merawang Sub-district, Bangka District, Bangka Island in March 2019 (204'21.4"S, $\left.105^{\circ} 52^{\prime} 12.0^{\prime \prime} \mathrm{E}\right)$ and in Lenggang River, Lintang Village, Simpang Renggiang Sub-district, East Belitung District, Belitung Island in May 2019 (255'09.5"S 10806'35.4"E) (Figure 1). The species did not comprise stock requiring special permits because it is included in the least concerned category in IUCN (Huckstorf 2012). The fishing gear used adjusts to the habits of local fishers.

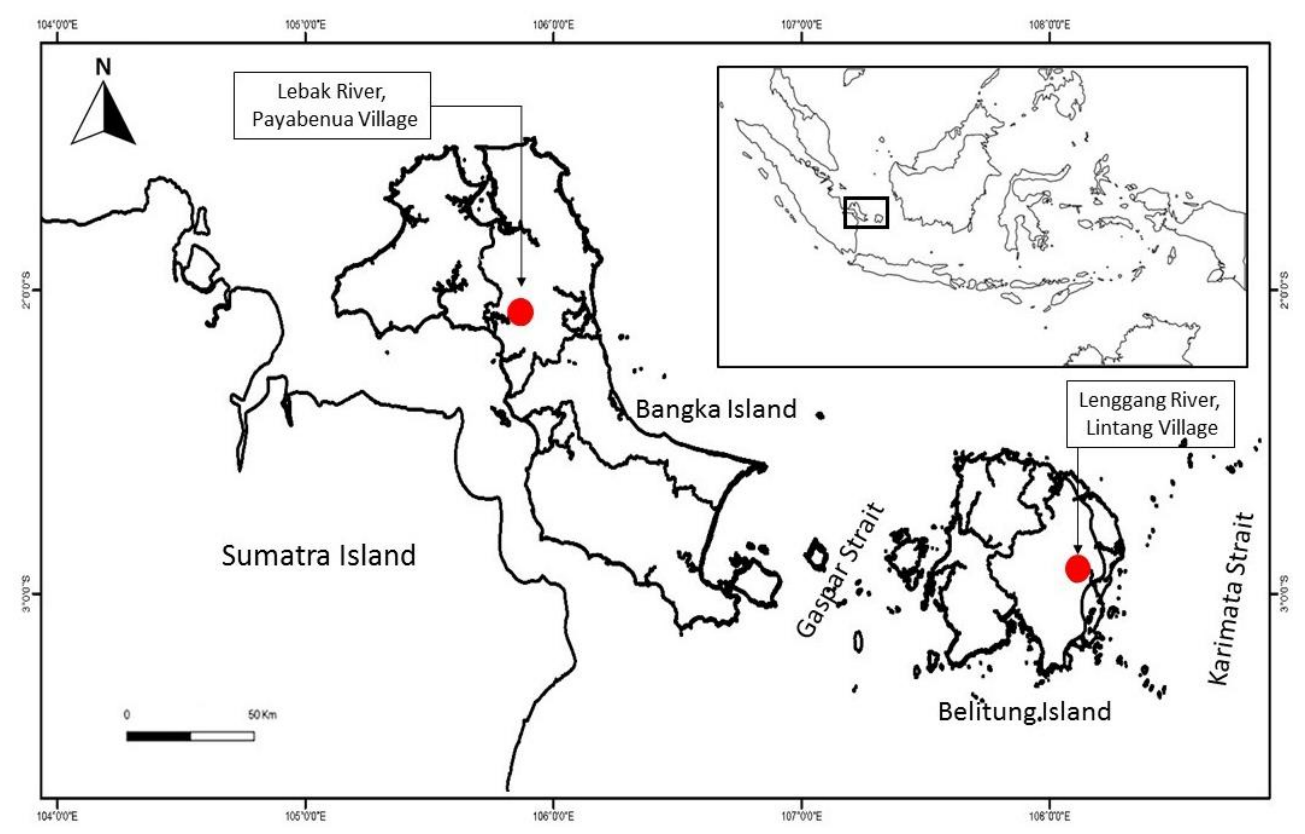

Figure 1. Sampling location of Osteochilus spilurus showing at Bangka and Belitung Islands, Indonesia 


\section{Procedures}

\section{Sample preservation}

Thirty (30) individuals were collected from Bangka and twenty-five individuals from Belitung, each with morphological characteristics for $O$. spilurus. The species verification using morphological keys provided by Weber and de Beaufort (1916). Individually of samples were measured manually using a digital caliper with a precision of $0.1 \mathrm{~mm}$. Measurements were made on the 15 morphometric characters observed (Figure 2). Measurement results are presented in the minimummaximum range and median. Five valid specimens of fish were drawn at random for DNA isolation. Whole-body specimens were subsequently stored in $96 \%$ ethanol until reaching the laboratory (Hasan and Tamam 2019). After a subsequent morphological assessment, all samples were kept below $-20^{\circ} \mathrm{C}$ in the Ichthyology Laboratorium of Brawijaya University.

\section{DNA isolation}

A small portion of the right pectoral fin was excised and retained in TNESU8 buffer for molecular studies. DNA extraction used TNESU8 buffer containing a high concentration of urea and SDS from DNase to digest DNA in the sample. Four hundred (400) $\mu \mathrm{l}$ of TNESU8 was added with $100 \mathrm{mg}$ of fish fin samples in a sterile microtube (Kusuma et al. 2017). Genomic DNA was extracted using the phenol method, a procedure described by Asahida et al. (1996). Twenty (20) $\mu \mathrm{l}$ of $20 \mathrm{mg} / \mathrm{ml}$ proteinase $\mathrm{K}$ slock solution was added to the DNA sample suspension, and the sample was shaken at $150 \mathrm{rpm}$ at $37^{\circ} \mathrm{C}$ overnight. Subsequently, $50 \mu \mathrm{l}$ of $\mathrm{NaCl} 5 \mathrm{M}$ and $500 \mu \mathrm{l}$ of phenol/chloroform (1:1) were added, and sample vortexed for 5 minutes. The suspension was centrifuged at 12000 rpm at cold temperature for 10 minutes. Three hundred (300) $\mu \mathrm{l}$ of chloroform/isoamyl alcohol (24:1) was added to $100 \mu \mathrm{l}$ of the supernatant, and the result was centrifuged for 10 minutes at $12000 \mathrm{rpm}$ at cold temperature.

DNA binding was carried out by adding $1000 \mu \mathrm{l}$ of cold $96 \%$ ethanol to $100 \mu \mathrm{l}$ of supernatant. The suspension was vortexed for 5 minutes and inserted into a GD column, which was already attached to the collection tube. The suspension was centrifuged for 1 minute at $5000 \mathrm{rpm}$ at a cold temperature. Precipitation was completed by removing the filtrate in the collection tube. The collection tube was washed with $800 \mu \mathrm{l}$ of cold $70 \%$ ethanol and dried before reattaching to the GD column. Subsequently, the collection tube was centrifuged at $12000 \mathrm{rpm}$ at a cold temperature for 5 minutes. In the results of this last centrifugation, remaining liquid was taken by removing the collection tube. The resulting pellets were dissolved in $200 \mu \mathrm{l}$ TrisEDTA buffer and stored in a freezer.

\section{DNA sequencing}

The amplified in a polymerase chain reaction (PCR) used primary GluDG-L (5'-TGACTTGAARAACCAYC GTTG-3') and CB2-H (5'-CCCTCAGAATGAT ATTTGT CCTCA-3') (Palumbi et al. 1991). The PCR was performed in a $10 \mathrm{ul}$ reaction mixture with a My Taq HS Red Mix from Bioline ${ }^{\mathrm{TM}}$ according to the manufacture's protocol. The PCR cycles were: 30 cycles of $98^{\circ} \mathrm{C}$ for 5 seconds, $55^{\circ} \mathrm{C}$ for 15 seconds, and $72^{\circ} \mathrm{C}$ for 20 seconds. Qualitative data analysis on PCR products was carried out by electrophoresis method on $0.8 \%$ agarose gel for band observation. The best of two PCR products from each island sample were sequenced using Applied Biosystems on the $1^{\text {st }}$ Base services.

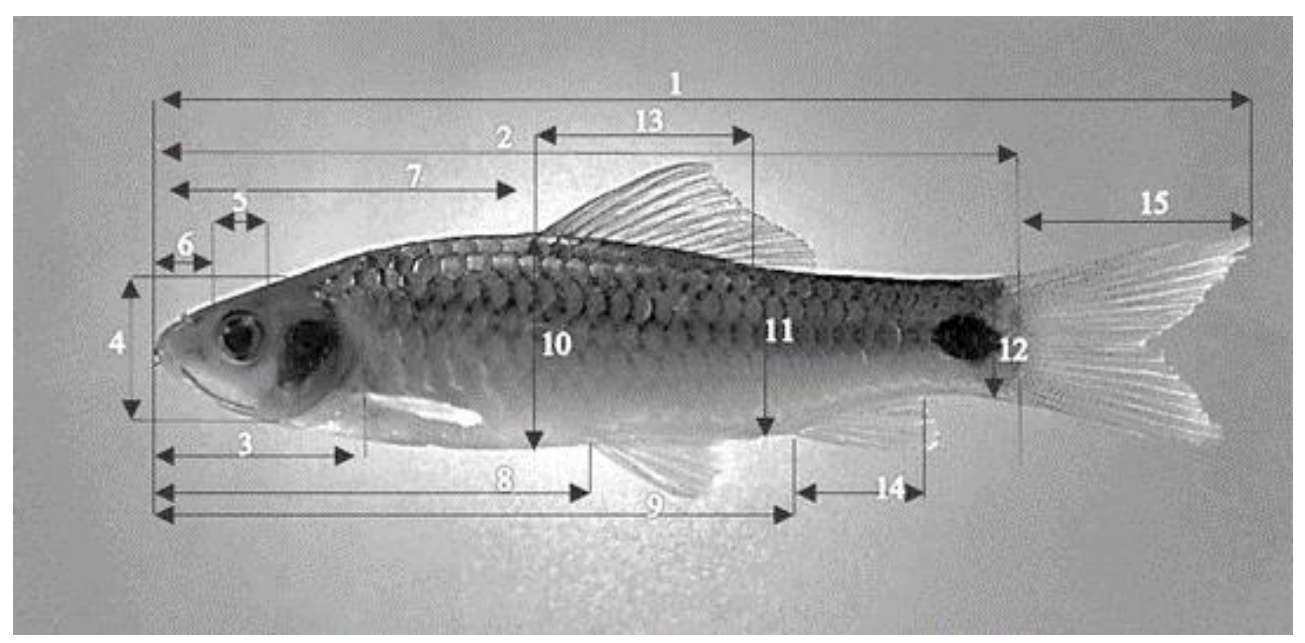

Figure 2. The fifteen morphometric measurements of Osteochilus spilurus (Kurniawan et al. 2020b) (1.Total length, 2. Standard length, 3.Head length, 4.Head depth, 5.Eye diameter, 6.Snout length, 7.Pre-dorsal length, 8.Pre-ventral length, 9.Pre-anal length, 10.Body depth at dorsal fin, 11.Body depth at anal fin, 12. Caudal pundacle depth, 13.Dorsal base length, 14.Anal base length, 15. Caudal fin length) 
Table 1. Comparative sequences of the genus Osteochilus and the outgroup

\begin{tabular}{lllc}
\hline \multicolumn{1}{c}{ Species } & \multicolumn{1}{c}{ Country } & \multicolumn{1}{c}{ Locality } & GenBank accession number \\
\hline Osteochilus spilurus & Indonesia & Lebak river, Bangka & MT372794*, MT372795* \\
& & Lenggang river, Belitung & MT372796*, MT372797* \\
& Malaysia & Balung river, Tawau, Sabah, Borneo & DQ366162.1, DQ366161.1 \\
Osteochilus waandersii & - & Aquarium & JX074267.1 \\
Osteochilus vittatus & Cambodia & Landing port, Kampong Chhnang & JX074226.1 \\
Osteochilus lini & Thailand & - & JX074265.1 \\
Osteochilus salsburyi & China & Rong' an, Guangxi & HM536787.1 \\
Osteochilus microcephalus & Cambodia & Market, Kampong Chhnang & JX074266.1 \\
Labiobarbus lineatus & China & Mengna, Yunnan & HM536789.1 \\
Labiobarbus spilopleura & Cambodia & Siem Reap & JX074203.1 \\
\hline Basector
\end{tabular}

Based on Yang et al. (2012) except the (*)sign is an accessed number for these research specimens

\section{Data analysis}

The sequence data were translated into amino acids to confirm the absence of premature stop codons. The forward and reverse sequences were edited using the Chroma 2.6.6 program, with the consensus drawn up using the Ugene 1.32 program, and the comparison sequences were applied using the Mesquite program. Sequences from Bangka Belitung Islands, O. spilurus from Sabah, other species within the genus Osteochilus (Yang et al. 2012), and outgroups were used for maximum likelihood phylogenetic reconstruction of the Kimura 2-parameter model, which is implemented in MEGA 10 with 1000 replicates bootstrapping data sets (Kimura 1980). A list of comparison sequences referred to is provided in Table 1. Phylogenetic trees inferred from the Cyt b sequences were rooted in Labiobarbus spilopleura (family: Cyprinidae) as the outgroup.

\section{RESULTS AND DISCUSSION}

\section{Description of sampling location}

Samples of Osteochilus spilurus on Bangka Island were obtained from fishers in the upper reaches of the Lebak River. Lebak River has a width of 17.8 - $25.95 \mathrm{~m}$ and empties into the Bangka Strait. Pandanus helicopus dominates the water plants on the river banks. Unlike other rivers on Bangka Island, the Lebak River has not been touched by tin mining, polluting the waters. Lebak River water has a temperature ranging from $29.1-29.3^{\circ} \mathrm{C}$, dissolved oxygen $6.6-7.8$ and tends to be acidic with a $\mathrm{pH}$ of 5.6 - 5.85. At another sampling, the location for Belitung Island is in the middle of the Lenggang River. This river was dammed during the Dutch colonial period to keep tin dredgers operational during the dry season. A dam's existence causes the river to have a width of between 230 $1,520 \mathrm{~m}$, with the dam's lowest width. Tin mining is a prohibited activity in this river, but it still occurs illegally, impacting the river water's turbidity. The waters in the sampling location have a temperature of $29.1-32.8^{\circ} \mathrm{C}$, dissolved oxygen 5.41 - 5.91, and acidity of $\mathrm{pH} 5$. Pandanus helicopus, which is called Rasau by the local community, also dominates aquatic plants on the riverbanks. The Lebak and Lenggang rivers' conditions with Pandanus helicopus adorning their banks are illustrated in Figure 3.

Fishers in Lebak river, Bangka, use a fishing trap called Tuguk. Tuguk is a traditional technology for local fishers in Bangka, a series of cone-shaped fishing nets installed against river currents (Afriansyah et al. 2019). The main target catch is not $O$. spilurus because this fish has no economic value in Bangka. Generally, fishers target higher economic value fish like Wallago leeri, Mystus nemurus, and Channa micropeltes. The opposite happened in Belitung. Catching O. spilurus in the Lenggang River is the primary income source for river fishers. Market and price are sure with the demand of more than $85 \%$ of East Belitung residents, especially Gantung Sub-district, who like to consume it (Kurniawan and Triswiyana 2019). They use a trapper called Sero. This tool has a wooden frame in the shape of a square covered with a small-edged net and has a mouth on one side. Fishers use the area around the plant on the riverbank to set fishing traps. Sero direction is contrary to the river flow direction as fishers realize $O$. spilurus practice of going toward the riverbank in groups as the river's flow rises. Most of the catch in the Lenggang river occurs at the beginning of the rainy season when water flows appear due to increased water volume from rain.

\section{Morphological verification}

Fish specimens from Bangka and Belitung have morphological characters as silvery body and more dark on the upside, snout tends to cone with several small pores, the height gradually increases from the snout to dorsal fin, the origin of the dorsal-fin located on the eighth scale of lateral line, slightly rounded anal fin located behind the dorsal fin, ventral fin locates behind the pectoral fin, caudal fin emarginate in shape, there is a large black blotch on caudal peduncle, has a pair of tentacles at the lower mouth, dorsal fin rays 3.11 to 3.12 , anal fin rays 3.5 , pectoral rays 1.12 , and a lateral line with 29 to 30 attached scales along the route. The morphometric ratio of specimens is a compressed body shape with a total length of 4.2 to 4.8 times the body height and 5.4 to 5.5 times the head length, and maxillary barbels are much longer than the eye. All of the observed characters relate to morphological key characters, as described by Weber and de Beaufort (1916). A picture of specimens from Belitung and Bangka islands 
is presented in Figure 4, showing that they are very similar to one another. In terms of morphological features, specimens from both islands were extremely similar, and they shared meristic characteristics. That result is in line with previous comparative findings, which showed that $O$. Spilurus from Bangka and Belitung islands carry the same meristic and morphometric characteristics (Kurniawan et al. 2020b). These characteristics are similar to O. spilurus from North Borneo, most of whom came from the Tawau District (Inger and Kong 1962). The result of the fifteen morphometric measurements of specimens from Bangka and Belitung island are presented in Table 2. Generally, the median of measurements on Bangka specimens is larger because they have a wider size range.
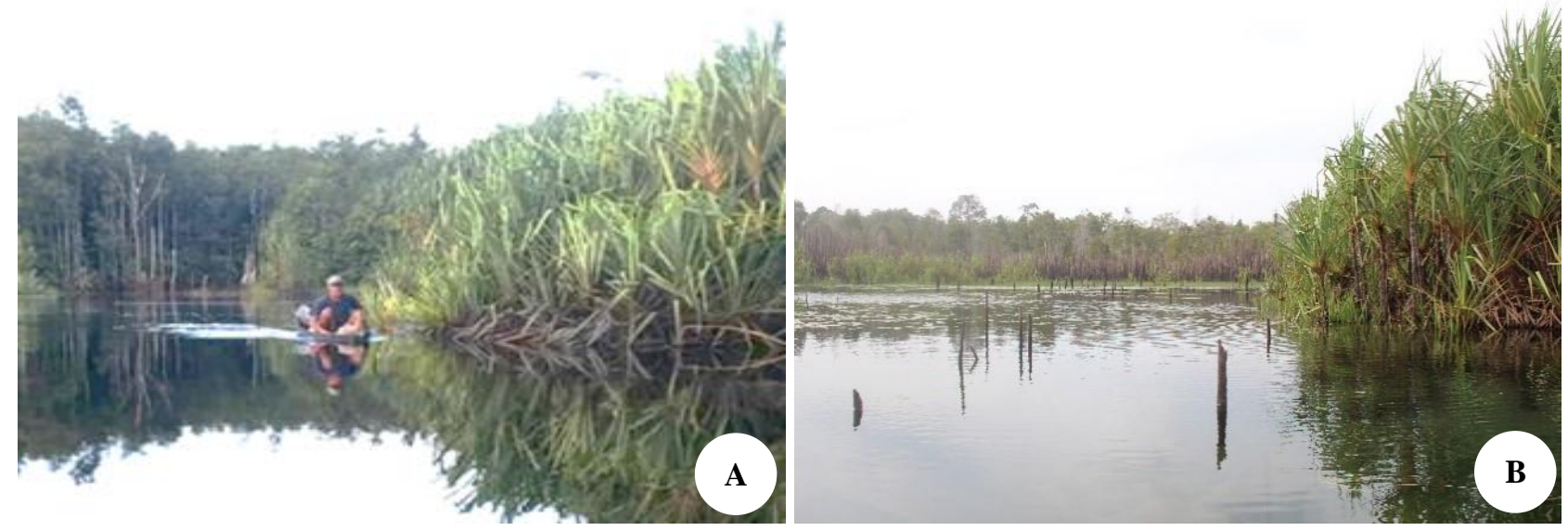

Figure 3. Conditions of the Lebak River (A) and the Lenggang River (B) in Kepulauan Bangka Belitung Province, Indonesia
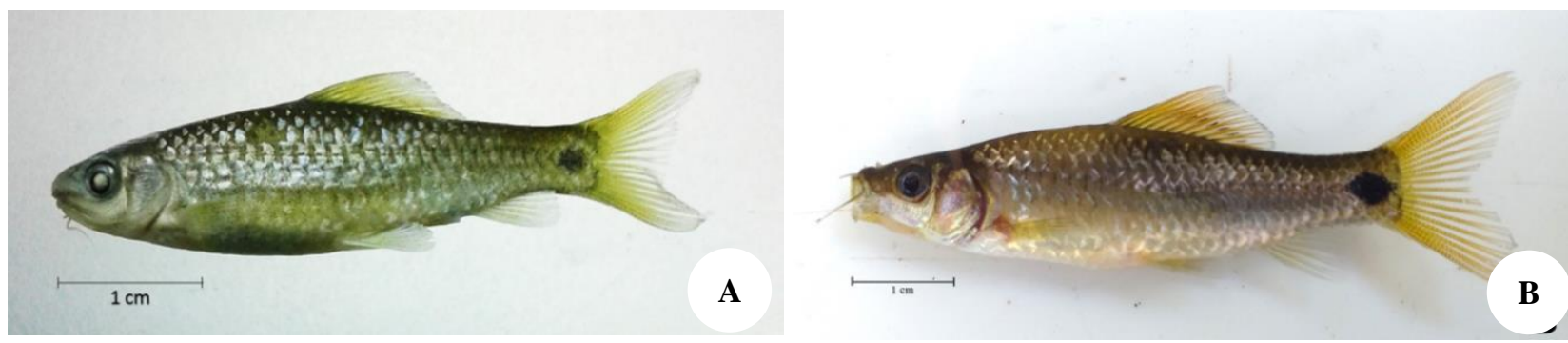

Figure 4. Morphology of Osteochilus spilurus from Belitung Island (A) and Bangka Island (B) of Kepulauan Bangka Belitung Province, Indonesia

Table 2. Morphometric measurement of Osteochilus spilurus from Bangka and Belitung Islands, Indonesia

\begin{tabular}{lcccc}
\hline \multirow{2}{*}{\multicolumn{1}{c}{ Character }} & \multicolumn{2}{c}{ Bangka Island $(\mathbf{n}=\mathbf{3 0})$} & \multicolumn{2}{c}{ Belitung Island (n=25) } \\
\cline { 2 - 5 } & Measurement $(\mathbf{m m})$ & Median & Measurement (mm) & Median \\
\hline Total Length & $36.1-73.4$ & 46.6 & $44.3-53.6$ & 49.8 \\
Standard length & $27.4-58.8$ & 35.6 & $35.6-46.8$ & 39.7 \\
Head length & $8.0-14.9$ & 9.8 & $7.5-10.1$ & 8.7 \\
Head depth & $5.6-10.6$ & 7.1 & $4.6-7.6$ & 6.9 \\
Eye diameter & $2.2-4.0$ & 2.8 & $2.4-3.5$ & 3 \\
Snouth length & $2.0-4.7$ & 2.8 & $1.9-3.1$ & 2.5 \\
Pre-dorsal Length & $12.9-26.9$ & 17.3 & $14.9-19.8$ & 17.9 \\
Pre-ventral Length & $15.3-31.3$ & 20.1 & $17.0-26.1$ & 20.3 \\
Pre-anal Length & $19.6-43.3$ & 27.1 & $25.9-31.7$ & 29.1 \\
Body depth at origin dorsal fin & $6.8-16.3$ & 10.2 & $9.7-12.1$ & 10.6 \\
Body depth at origin anal fin & $4.7-12.0$ & 6.9 & $5.7-7.7$ & 6.7 \\
Caudal pundacle depth & $3.6-8.2$ & 4.8 & $3.8-5.3$ & 4.4 \\
Dorsal base length & $7.5-19.1$ & 11.1 & $6.3 .-9.8$ & 8.4 \\
Anal base length & $2.8-5.9$ & 3.6 & $2.5-4.0$ & 3.2 \\
Caudal fin length & $7.2-14.8$ & 10.8 & $8.9-11.7$ & 10.5 \\
\hline
\end{tabular}




\section{Genetic and phylogenetic identification}

The Cyt $b$ gene from each fish specimen was successfully amplified, resulting in a clear and specific band. A comparison with the DNA ladder showed the band of PCR product at $408 \mathrm{bp}$. Four PCR products were sequenced and produced normal chromatograms. There were no premature stop codons on any of the sequences. Editing and consensus of sequences produced four sequences with a length of $408 \mathrm{bp}$. Nucleotides had composition of thymine $(28.7 \%)$, cytosine $(26.2 \%)$, adenine $(30.6-31.1 \%)$, and guanine $(14.0-14.5 \%)$. No length variations, deletions, or insertions were observed for any of the sequences. The condition of no polymorphisms of sequence from the Bangka Belitung Islands and adenineguanine variance is related to Yang et al. (2012) study of the Cyt b sequence of fish species from the Osteochilus genus. Guanine deficits are usually in the third codon's mtDNA coding position (Zaccara et al. 2007). All four sequences have a $100 \%$ cover as they query each other. Samples from Belitung (LG12 and LG 8) showed a similarity of $98.53 \%$, while LG12 with samples from Bangka (LB2 and LB5) had a greater similarity of $99.75 \%$. The four nucleotides were deposited in NCBI with accession numbers MT372794, MT372795 for Bangka Island, and MT372796, MT372797 for Belitung Island. Presently, there are eight nucleotides for the species $O$. spilurus recorded in NCBI, with four records from Tawau, Sabah, Malaysia, and four records from this study (Tabel 2 ). This indicates that the record for nucleotides $O$. spilurus from the Bangka and Belitung islands form Indonesia's latest and the first record.

Cyt b sequences trimmed to the same length as those from GenBank, so the final data-set for phylogenetic reconstruction comprised sequences of 426 bp for 14 specimens. Phylogenetic tree analyses using the maximum likelihood method showed that the Bangka and Belitung Islands specimens were clustered together and formed a monophyletic clade (Figure 5). The genetic distance between the four specimens was between 0 to $1.5 \%$ (Table 4).

Table 3. Genetic record of Osteochilus spilurus in GeneBank (NCBI 2020)

\begin{tabular}{cccl}
\hline GeneBank accesion number & Gene & NCBI Released time & \multicolumn{1}{c}{ Location } \\
\hline EU136582.1 & 16S ribosomal RNA (726 bp) & 25-Sep-2007 & Malaya Peninsular \\
EU136581.1 & 16S ribosomal RNA (726 bp) & 25-Sep-2007 & Malaya Peninsular \\
DQ366161.1 & Cyt b (408 bp) & 26-Jul-2016 & Malaysia: Balung River, Tawau, Sabah \\
DQ366162.1 & Cyt b (408 bp) & 26-Jul-2016 & Malaysia: Balung River, Tawau, Sabah \\
MT372797.1 & Cyt b (408 bp) & 31-May-2020 & Indonesia: Lenggang River, Belitung Island* \\
MT372796.1 & Cyt b (408 bp) & 31-May-2020 & Indonesia: Lenggang River, Belitung Island* \\
MT372795.1 & Cyt b (408 bp) & 31-May-2020 & Indonesia: Lebak River, Bangka Island* \\
MT372794.1 & Cyt b (408 bp) & 31-May-2020 & Indonesia: Lebak River, Bangka Island* \\
\hline
\end{tabular}

Note: *) The sign is a genetic record from this research

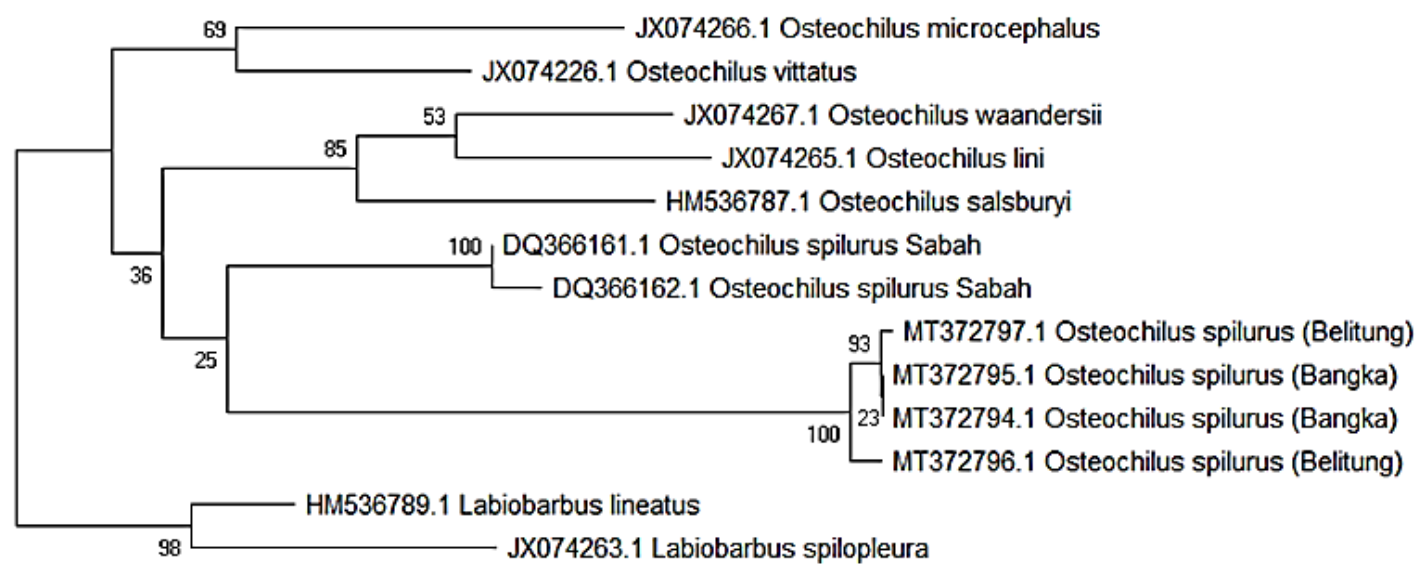

0.020

Figure 5. A maximum-likelihood phylogenetic tree with 1000 bootstrap replicates. Specimens from Bangka and Belitung are clustered together with a strong bootstrap value (100\%). Labiobarbus spilopleura and L.lineatus are two species in the genus Cyprinidae used as an outgroup 
Table 4. The distance of Osteochilus spilurus sequences from Bangka and Belitung islands with other species in Osteochilus genus on cyt $b$ gene

\begin{tabular}{|c|c|c|c|c|c|c|c|c|c|c|}
\hline Species & 1 & 2 & 3 & 4 & 5 & 6 & 7 & 8 & 9 & 10 \\
\hline \multicolumn{11}{|l|}{ MT372796 O. spilurus (Belitung) } \\
\hline MT372797 O. spilurus (Belitung) & 0.0149 & & & & & & & & & \\
\hline MT372795 O. spilurus (Bangka) & 0.0124 & 0.0025 & & & & & & & & \\
\hline MT372794 O spilurus (Bangka) & 0.0124 & 0.0025 & 0.0000 & & & & & & & \\
\hline DQ366162.1 O. spilurus (Sabah) & 0.2066 & 0.2105 & 0.2066 & 0.2066 & & & & & & \\
\hline DQ366161.1 O. spilurus (Sabah) & 0.1886 & 0.1923 & 0.1886 & 0.1886 & 0.0100 & & & & & \\
\hline JX074226.1 O. vittatus & 0.2051 & 0.2089 & 0.2051 & 0.2051 & 0.1416 & 0.1343 & & & & \\
\hline JX074266.1 O. microcephalus & 0.2077 & 0.2034 & 0.1991 & 0.1991 & 0.1640 & 0.1640 & 0.1236 & & & \\
\hline HM536787.1O. salsburyi & 0.1943 & 0.2020 & 0.1981 & 0.1981 & 0.1588 & 0.1436 & 0.1698 & 0.1640 & & \\
\hline JX074267.1 O. waandersii & 0.1793 & 0.1757 & 0.1720 & 0.1720 & 0.1662 & 0.1507 & 0.1703 & 0.1483 & 0.1164 & \\
\hline JX074265.1 O. lini & 0.2215 & 0.2136 & 0.2097 & 0.2097 & 0.1545 & 0.1427 & 0.1732 & 0.1797 & 0.1099 & 0.0928 \\
\hline
\end{tabular}

The genetic gap of specimens from Bangka and Belitung islands were below $2 \%$. The gap range includes low distance, between $0-1.49 \%$. That means they have a genetic similarity of $98.5-100 \%$. It is in line with the similarity of morphological characteristics, which have identical meristic characters of $O$. spilurus. This ensures that the differences in morphometric and body shape (Kurniawan et al. 2020c) in the O. spilurus of the two islands not due to genetic variation. Phenotypic differences that are not followed by genotypic differences can be interpreted as morphological plasticity (Vences et al. 2002). Plasticity reflects the fish's adaptive responses to environmental conditions (O'Reilly and Horn 2004).

Bangka-Belitung nucleotides showed a close relationship with Sabah, North Borneo one, although only supported with a low bootstrap value. This close relationship suggests the possibility of the same species was greater than other Osteochilus species. The genetic distance between Bangka-Belitung and North Borneo nucleotides, which geographically separated for 1313 $1482 \mathrm{~km}$, was 18.9 to $21 \%$. The same freshwater fish species can have high genetic distances in individuals separated by distances and geographic barriers. Channa striata, one of the famous native freshwater fish from the Malay Peninsula, Sumatra, and Borneo, appear on the same branch with low bootstrap values (Tan et al. 2012). Mystus singaringan from Java Island and Thailand in the Asia continent, separated by more than $2,000 \mathrm{~km}$, shows a genetic distance between 14 and 26\% (Pramono et al. 2019). Species determination based on morphological characters still plays an important role when genetic identification shows a non-conformity.

$O$. spilurus are on the same branch and separate from other Osteochilus. The sameness of branches means that many years ago, they are the same species. This may be related to the sea level at Sundaland in the past. The Asian continent was linked to Borneo, Sumatra, Java, and Bangka Belitung's Islands in the Pleistocene period (Hall and Morle 2004). At that time, sea levels were more than 50m under present conditions (Voris 2000). The connection of these islands allowed connectivity of ancient rivers in them. Two ancient rivers connected the islands, namely North Sunda (connecting the central part of Sumatra, Bangka, Belitung, and the western part of Borneo) and East Sunda (Southern
Sumatra, Belitung, Java, and Southern Borneo) (Hutama et al. 2016; Saptadjaja et al. 2020). Ancient species that are widely distributed in the Sundaland had geographic isolation when sea levels rise.

The evolutionary variations that appear in genetic distances are believed to be due to geographical isolation and environmental changes. Bangka, Belitung, and Borneo have been separated by sea as caused geographical isolation. Sea is one of the geographical walls for natural freshwater fish distribution (Zaccara et al. 2007). The ocean barriers for $O$. spilurus distribution in this research are Gaspar strait and Karimata strait. Gaspar strait separated Bangka and Belitung islands, and Karimata strait for both islands with Borneo island. The increase in sea level caused Borneo and Bangka-Belitung island to separate early, and the separation of Bangka and Belitung occurred after that. Bangka and Belitung are still on the same land with a depth of $30 \mathrm{~m}$ but separated from Borneo island. This separation occurred about 8,600 - 10,000 years before the present (Voris 2000). Historical biogeography becomes a barrier closely related to genetic variation (de Bruyn et al. 2005). Differences of historical time separation probably correlated with genetic distance variation of $O$. spilurus that Bangka to Belitung has smaller than the distance from Bangka-Belitung to Sabah.

The difference in fish evolution is possible due to adaptation to different environments, as the second reason for the evolutionary variation. River waters in Bangka and Belitung tend to be more acidic with a lower $\mathrm{pH}$. Acidic water conditions characterize most of Bangka and Belitung inland waters (Muslih et al. 2014b; Rustam and Prabawa 2015). Western Borneo, the region where this species is most commonly found (BGIF 2019), has a similar water acidity. The Kapuas River in Western Borneo, the most $O$. spilurus found, has water that tends to be acidic in the range of 5.5 to 6 (Adjie and Dharyati 2017). Similar water conditions with western Borneo do not happen in northern Borneo. The water of rivers in Tawau, Sabah, the origin of the first mitochondrial genetic record of $O$. spilurus, was reported to have a neutral acidity degree (Oksel et al. 2009). Differences in water acidity allow the fish to adapt to distinct directions. The gaps in water conditions were getting wider with habitat changes due to tin mining in Bangka and Belitung. Tin mining in the Bangka-Belitung 
islands became one of the differentiators of the river environment from Borneo island. Tin was excavated more than 350 years ago, since before Dutch colonialism in Indonesia and one of the world's largest producers (Ibrahim et al. 2018). The river is an area that is often affected by legal and illegal tin mining. The lead content in the soil is often related to river channels. The river that has experienced sedimentation due to mining waste has decreased numbers of fish species (Nurtjahya et al. 2017).

Finally, specimens from Bangka and Belitung Islands have a closer relationship with $O$. spilurus than other Osteochilus species. The mitochondrial nucleotide deposit of $O$. spilurus from Bangka and Belitung islands is Indonesia's first report. The morphological similarity of Bangka and Belitung Islands specimens was followed by the low genetic gap between them. Differences in the evolutionary process due to historical biogeography and environmental changes are predicted to have caused the low genetic similarity to O. spilurus from Sabah, North Borneo.

\section{ACKNOWLEDGEMENTS}

This work was supported by LPDP (Educational Fund Management Institution) in scholarship and research funding, Suci, Widya, Septiana, Messrs Faiq, and Azam in the laboratory assistance, Jenny and Fitri in the field assistance, and Wahyu Endra in the analysis discussion.

\section{REFERENCES}

Adjie S, Dharyati E. 2017. Distribution and food habits of several types of fish in the Kapuas River basin, West Kalimantan. Bawal 2 (6): 283 290.

Afriansyah B, Hidayati N, Pratiwi T, Fitrianingsih N. 2019. The fishing gears traditional of Malik Village, South Bangka Regency. In International Conference on Maritime and Archipelago (ICOMA 2018). Advances in Engineering Research. Atlantis Press, Amsterdam, Netherlands.

Asahida T, Kobayashi T, Saitoh K, Nakayama I. 1996. Tissue preservation and total DNA extraction from fish stored at ambien temperature using buffers containing high concentration of urea. Fish Sci 62 (5): 727-730. DOI: 10.2331/fishsci.62.727

De Bruyn M, Nugroho E, Hossain MM, Wilson JC, Mather PB. 2005. Phylogeographic evidence for the existence of an ancient biogeographic barrier: The Isthmus of Kra Seaway. Heredity 94 (3): 370-378

Esa YB, Japning R, Rahim KA, Siraj SS, Daud SK, Tan SG, Sungan S. 2012. Phylogenetic relationships among several freshwater fishes (Family: Cyprinidae) in Malaysia inferred from partial sequencing of the cytochrome b mitochondrial DNA (mtDNA) gene. Pertanika J Trop Agric Sci 35 (2): 307-318

Fahmi M, Ginanjar RR, Kusumah RV. 2015. Keragaman ikan hias di lahan gambut Cagar Biosfer Bukit-Batu, Propinsi Riau. Prosiding Seminar Nasional Masyarakat Biodiversitas Indonesia 1 (2): 51-58. DOI: $10.13057 / \mathrm{psnmbi} / \mathrm{m010108}$. [Indonesia]

Fakhrurrozi Y, Kurniawan A, Kurniawan A. 2016. Development of Cempedik fish potential in East Belitung: A biological and ethnobiological approach. Scripta Biologica 3 (4): 1-5

Hall R, Morle CK. 2004. Sundaland Basins. Continent-ocean Interactions Within East Asian Marginal Seas. American Geophysical Union, Washington DC, United States.

Haryono, Wahyudewantoro G. 2020. The freshwater fishes and species status of peatland areas in Central Kalimantan, Indonesia. Eco Env Cons 26: 14-19
Hasan V, Tamam MB. 2019. First record of the invasive Nile Tilapia, Oreochromis niloticus (Linnaeus, 1758) (Perciformes, Cichlidae), on Bawean Island, Indonesia. Check List 15 (1): 225-227. DOI: 10.15560/15.1.225.

Hsieh HM, Chiang HL, Tsai LC, Lai SY, Huang NE, Linacre A, Lee JCI. 2001. Cytochrome b gene for species identification of the conservation animals. Forensic Sci Intl 122 (1): 7-18. DOI: 10.1016/s0379-0738(01)00403-0.

Huckstorf V. 2012. Osteochilus spilurus. The IUCN Red List of Threatened Species 2012: e.T181063A1694304.

Hutama AA, Hadiaty RK, Hubert N. 2016. Biogeography of Indonesian freshwater fishes: Current progress. Treubia 43: 17-30. DOI: 10.14203/treubia.v43i0.2969

Ibrahim I, Haryadi D, Wahyudin N. 2018. From charm to sorrow: The dark portrait of tin mining in Bangka Belitung, Indonesia. PEOPLE: Intl J Soc Sci 4 (1): 360-382. DOI: 10.20319/pijss.2018.41.360382

Inger RF, Kong CP. 1962. The Freshwater Fishes of North Borneo. Chicago Histology Museum, Chicago.

Kimura M. 1980. A simple method for estimating evolutionary rate of base substitutions through comparative studies of nucleotide sequences. J Mol Evol 16 (2): 111-120. DOI: 10.1007/BF01731581.

Kottelat M, Whitten AJ, Kartikasari SN, Wirjoatmodjo S. 1993. Freshwater Fishes of Western Indonesia and Sulawesi. Periplus Editions, Hong Kong.

Kurniawan A, Azhari M, Prasetiyono E. 2019. Domestication of Osteochilus spilurus: Survival and growth in recirculated water. IOP Conf Ser: Earth Environ Sci 230 (1): 012116. DOI: 10.1088/1755$1315 / 230 / 1 / 012116$

Kurniawan A, Fakhrurrozi Y, Kurniawan A. 2016. Ethnozoological study of Cempedik fish in Lenggang River, Gantung, East Belitung Regency. Akuatik 10 (1): 6-12.

Kurniawan A, Hariati AM, Darmawan A, Wiadnya DGR. 2020 b. Morphometric comparison of Osteochilus spilurus (Bleeker 1851) from Bangka and Belitung Island, Indonesia. IOP Conf Ser: Earth Environ Sci 493 (1): 012024. DOI: 10.1088/17551315/493/1/012024.

Kurniawan A, Hariati AM, Kurniawan A, Haryono H, Wiadnya DGR. 2020c. Morphological comparative of Osteochilus spilurus (Cyprinidae) from three Sundaland Island in Indonesia using geometric morphometric. Egypt J Aquat Biol Fish 24 (7): 835-845

Kurniawan A, Pramono DY, Indrayati A, Hermanto H, Triswiyana I. 2020a. Differences in local perceptions of Osteochilus spilurus (Cyprinidae: Labeoninae) from several islands in Indonesia. Asian J Ethnobiol 3 (2): 79-84. DOI: 10.13057/asianjethnobiol/y030205

Kurniawan A, Triswiyana I. 2019. Perception of the economics utilization and sustainability of Cempedik fish (Osteochilus Spilurus) in East Belitung Regency. ECSOFiM 7 (1): 109-119. DOI: 10.21776/ub.ecsofim.2019.007.01.09

Kusuma WE, Samuel PD, Wiadnya DGR, Hariati AM, Kumazawa Y. 2017. Complete mitogenome sequence of Rasbora argyrotaenia (Actinopterygii: Cyprinidae). Mitochondrial DNA Part B 2 (2): 373374. DOI: 10.1080/23802359.2017.1347835

Lumbantobing D, Huckstorf V. 2020. Osteochilus spilurus. The IUCN Red List of Threatened Species 2020: e.T181063A91066472. DOI: 10.2305/IUCN.UK.2020-3.RLTS.T181063A91066472.en.

Muslih K, Adiwilaga EM, Adiwibowo S. 2014. Habitat characteristics and diversity of freshwater fish in the Menduk River that have been affected by tin mining in Bangka Regency. Akuatik J Aquat Resour 8 (2): 17-23.

Muslih K, Adiwilaga EM, Adiwibowo S. 2014. The effect of tin mining on river fish diversity and local wisdom of the people in Bangka Regency. Limnotek 21 (1): 52-63

Mustikasari D, Nuryanto A, Prabowo RE. 2018. The Morphological Characteristics of Cempedik Fish from Belitung Island. In: The SEA+ Conference on Biodiversity and Biotechnology 2018, Purwokerto, Indonesia, 07 November 2018.

National Center for Biotechnology Information (NCBI). Bethesda (MD): National Library of Medicine (US), National Center for Biotechnology Information; [1988] - [cited 2019 March 24]. https://www.ncbi.nlm.nih.gov/

National Center for Biotechnology Information (NCBI). Bethesda (MD): National Library of Medicine (US), National Center for Biotechnology Information [cited 09 September 2020]. https://www.ncbi.nlm.nih.gov/nuccore/?term=osteochilus $\% 20$ spilurus

Nurtjahya E, Franklin J, Agustina F. 2017. The Impact of tin mining in Bangka Belitung and its reclamation studies. In: MATEC Web of 
Conf EDP $\quad$ Sciences 101 . 04010. DOI: 10.1051/matecconf/201710104010

Oksel O, Razali N, Yusoff MK, Ismail MZ, Pa'ee KF, Ibrahim KN. 2009. The impacts of integrated farming to water quality: case study on Langgas River, Kunak, Sabah, Malaysia. Intl J Eng Technol 9 (9): 55 58.

O'Reilly KM, Horn MH. 2004. Phenotypic variation among populations of Atherinops affinis (Atherinopsidae) with insights from a geometric morphometric analysis. J Fish Biol 64 (4): 1117-1135. DOI: $10.1111 / \mathrm{j} .1095-8649.2004 .00379 . \mathrm{x}$

Palumbi S, Martin A, Romano S, McMillan WO, Stice L, Grabowski G. 1991. The Simple Fool's Guide to PCR. Department Zoology and Kewalo Marine Laboratory Publication, University of Hawaii, United States.

Pramono TB, Arfiati D, Widodo MS, Yanuhar U. 2019. Genetic characteristics of Senggaringan Fish (Mystus singaringan) from Klawing River, Brantas River and Thailand as the basis of conservation and domestication. Aquac Aquar Conserv Legis 12 (4) : 996-1004.

Radona D, Anang HK, Kurniawan K, Suparman, Edian T, Dodot DL. 2020. A preliminary study of Osteochilus spilurus (Bleeker 1851) domestication: Sex identification and bio-reproductive characters. J Fish Aquat Sci 15 (2): 35-41. DOI: 10.3923/jfas.2020.35.41

Rustam A, Prabawa FY. 2015. Manggar river water quality, Manggar city, East Belitung regency: Comparison of the rainy and dry seasons. In The Blue Economy of Coastal Resources. Pusat Penelitian dan Pengembangan Sumber Daya Laut dan Pesisir, Jakarta.

Saptadjaja AM, Hasan V, Arief M, Isroni W, Rozi. 2020. First record of threatened Asian Catfish, Clarias batrachus (Linnaeus, 1758)
(Siluriformes, Clariidae) from Kangean Island, Indonesia. Ecol Environ Conserv 26 (3): 1055-1058.

Tan MP, Jamsari AFJ, Azizah MNS. 2012. Phylogeographic pattern of the striped snakehead, Channa striata in Sundaland: Ancient river connectivity, geographical and anthropogenic signatures. PLoS One 7 (12): e52089. DOI: 10.1371/journal.pone.0052089

Vences M, Puente M, Nieto S, Vieites DR. 2002. Phenotypic plasticity of anuran larvae: Environmental variables influence body shape and oral morphology in Rana temporaria tadpoles. J Zool 257 (2): 155-162. DOI: $10.1017 /$ S0952836902000754

Voris HK. 2000. Maps of Pleistocene sea levels in Southeast Asia: Shorelines, river systems, and time durations. J Biogeogr 27 (5): 1153-1167. DOI: 10.1046/j.1365-2699.2000.00489.x

Ward RD, Hanner R, Hebert PD. 2009. The campaign to DNA barcode all fishes, FISH-BOL. J Fish Biol 74 (2): 329-356. DOI: 10.1111/j.10958649.2008.02080.x

Weber MWC, de Beaufort LF. 1916. The Fishes of the Indo-Australian Archipelago Volume 3. EJ Brill Limited, Netherlands.

Yang L, Arunachalam M, Sado T, Levin BA, Golubtsov AS, Freyhof J, Friel JP, Chen W, Hirt MV, Manickam R, Agnew MK, Simons AM, Saitoh K, Miya M, Mayde RL. 2012. Molecular phylogeny of the cyprinid tribe Labeonini (Teleostei: Cypriniformes). Mol $\begin{array}{lllll}\text { Phylogenetics } & \text { Evolut } 65 & \text { (2): 362-379. DOI: }\end{array}$ 10.1016/j.ympev.2012.06.007

Zaccara S, Stefani F, Delmastro GB. 2007. Phylogeographical structure of vairone Telestes muticellus (Teleostei, Cyprinidae) within three European peri-Mediterranean districts. Zoologica Scripta 36 (5): 443453. DOI: $10.1111 /$ j.1463-6409.2007.00294.x 